\title{
The feeding response of a marine planktonic copepod to quantity and quality of particles
}

\author{
Gustav-Adolf Paffenhöfer \& Kay B. Van Sant* \\ 'Skidaway Institute of Oceanography, P. O. Box 13687, Savannah, Georgia 31416, USA
}

\begin{abstract}
Particles of varying food quality but similar size were offered singly and in mixtures to copepodid Stage $\mathrm{V}$ of Eucalanus pileatus to determine the rates at which calanoid copepods ingest naturally occurring particulate matter. The sequence of ingestion rate was: living phytoplankton cells $>$ dead phytoplankton cells $>$ fecal pellets $>$ polystyrene spheres. Cinematographic observations revealed that both long range and short range chemoreception contributed to these differences. Living phytoplankton cells were ingested at rates 1.2 to 3 times higher than similarly-sized non-living food particles. Non-food particles offered alone were not ingested. In mixtures, the rate at which non-food particles were ingested was a function of the feeding rate on food particles. At environmental concentrations the presence of non-food particles does not appear to reduce feeding rates on food particles.
\end{abstract}

\section{INTRODUCTION}

A variety of particles of different food quality and size are ingested by zooplankton (Conover \& Huntley 1980). Some zooplankton taxa discriminate between particles of different quality (Donaghay \& Small 1979) while others do not [appendicularia (Alldredge 1981), and probably thaliacea]. The ability to discriminate between particles of high and low quality would be an advantage in environments where high-quality food is relatively scarce. Indiscriminate feeding, on the other hand, may conserve energy required to separate highand low-quality food. Appendicularia feed indiscriminately mainly on particles smaller than $15 \mu \mathrm{m}$ (Lohmann 1909, Alldredge 1981, Paffenhöfer unpubl.). Thaliacea appear to indiscriminately ingest particles $\geq$ $1 \mu \mathrm{m}$ (Harbison \& McAlister 1979).

Calanoid copepods discriminate between valuable (phytoplankton cells) and non-valuable particles (polystyrene beads) either by rejecting the latter (Donaghay \& Small 1979) or ingesting them at very low rates (Frost 1977, Fernandez 1979, Donaghay 1980. Huntley et al. 1983). Some calanoids (e.g. Calanus helgolandicus), on the other hand, ingest large

\footnotetext{
- Present address: Marine Resources Center, P. O. Box 12559 Charleston, South Carolina 29412, USA
}

amounts of valueless particles when phytoplankton cells are also available (Paffenhöfer 1972). The estuarine calanoid Acartia tonsa ingests large amounts of detritus (Roman 1984), and the calanoid Undinula vulgaris subsists mainly on detritus (Gerber \& Marshall 1974). Poulet (1983) summed up our present knowledge on feeding processes of zooplankton by stating 'How zooplankton make the decision to capture a fraction of their food from living resources and the remainder from the detritus food chain is unknown'.

The objectives of our study were to determine the clearance and ingestion rates of living and dead phytoplankton cells, copepod fecal pellets and polystyrene beads, offered separately and in mixtures, by the neritic calanoid copepod Eucalanus pileatus. We also used cinematography to directly observe feeding behavior when the copepod was offered some of these particles. Fecal pellets and dead phytoplankton cells were intended to represent detritus of some food value, and polystyrene beads particles of no food value.

\section{MATERIALS AND METHODS}

The neritic calanoid copepod Eucalanus pileatus Copepodid Stage V (CV) was used in our experiments. The copepods were collected as CIII or CIV and accli- 
mated for 48 to $72 \mathrm{~h}$ to experimental conditions. During this acclimation period CIV moulted to $\mathrm{CV}$ within 24 to $48 \mathrm{~h}$. Little mortality occurred during the experiments. All studies were run at $20^{\circ} \mathrm{C}$ in a light-dark cycle of 14:10 h. High-speed movies were made with fertilized E. pileatus females, usually acclimated to experimental conditions for $48 \mathrm{~h}$ (Price et al. 1983).

Feeding experiments of between 9 and $22 \mathrm{~h}$ were conducted in 480 or $960 \mathrm{ml}$ screw cap bottles fastened to a Ferris Wheel. Each experiment had at least 1 control jar (without copepods). All clearance and ingestion rate calculations are based on direct cell counts under a microscope. The diatoms Rhizosolenia alata (16 to $24 \mu \mathrm{m}$ diameter, 150 to $350 \mu \mathrm{m}$ cell length) and Thalassiosira weissflogii (11 to $14 \mu \mathrm{m}$ width) were grown in f/10-medium (Guillard \& Ryther 1962). Dead algae, representing one form of detritus, were obtained by slowly heating $R$. alata to $65^{\circ} \mathrm{C}$, maintaining them at that temperature for $5 \mathrm{~min}$, and then placing them in a $20^{\circ} \mathrm{C}$ chamber, where they reached $20^{\circ} \mathrm{C}$ within hours. These algae were then gently removed from the water, suspended in glass-fibre filtered seawater at a concentration of $5 \mathrm{~mm}^{3} \mathrm{l}^{-1}$ and kept on a Ferris Wheel for 5 to $6 \mathrm{~d}$. This treatment reduced the carbon and nitrogen per cell to 50 to $70 \%$ of the original (living cell) concentration. Three samples for inverted microscope counts were drawn from each experimental jar and control at the beginning and end of the experimental period. Feeding rates were calculated after Frost (1972).

Fecal pellets were produced by feeding Paracalanus spp. CV and females the prymnesiophycean Isochrysis galbana at initial concentrations of 1.5 and $2 \mathrm{~mm}^{3} \mathrm{l}^{-1}$. After 20 to $24 \mathrm{~h}$ the pellets produced were gently separated from the remaining phytoplankton cells using $10 \mu \mathrm{m}$ mesh and were offered within $5 \mathrm{~h}$ to Eucalanus pileatus CV. Pellet diameters were usually between 20 to $30 \mu \mathrm{m}$ with lengths ranging from 90 to about $200 \mu \mathrm{m}$. Average pellet volumes ranged from 0.5 to $1 \times 10^{5} \mu \mathrm{m}^{3}$. The average pellet nitrogen content was $53.7 \pm 16.4 \mu \mathrm{g} \mathrm{mm}^{-3}$ (95\% confidence limits) and the average $\mathrm{C}: \mathrm{N}$ ratio $6.35 \pm 0.62$

Polystyrene beads offered in experiments had an average diameter of $20 \mu \mathrm{m}$ while those used for visual observations were $18 \mu \mathrm{m}$ diameter. As bead consumption by Eucalanus pileatus was always low, clearance and ingestion rates were determined from the number of pellets produced per copepod and the average number of beads per pellet (Fernandez 1979).

The method used to film copepod feeding behavior was similar to that employed by Price et al. (1983). Hairs were glued onto Eucalanus pileatus females 18 to $24 \mathrm{~h}$ prior to filming. The films were analysed with a Vanguard Motion Picture Analyser.

All experiments were conducted at average vol- umetric particle concentrations ranging from the lowest (ca 0.1 ) to the highest ( $\mathrm{ca} 3.0 \mathrm{~mm}^{3} \mathrm{l}^{-1}$ ) encountered in nearshore and offshore waters on the southeastern continental shelf of the USA.

\section{RESULTS}

When Eucalanus pileatus $\mathrm{CV}$ were offered each of the different particles separately at an average nonsatiating concentration of $0.3 \mathrm{~mm}^{3} \mathrm{I}^{-1}$, living Rhizosolenia alata cells were eaten at higher rates than dead $R$. alata, fecal pellets of similar size and the smaller diatom Thalassiosira weissflogii. Polystyrene spheres were not ingested except during the first minutes of an experiment (Table 1).

Table 1. Eucalanus pileatus CV. Average clearance rates (ml swept clear copepod ${ }^{-1} 24 \mathrm{~h}^{-1}$ ). Average food concentration ca $0.3 \mathrm{~mm}^{3} \mathrm{l}^{-1}$ in each experiment

\begin{tabular}{|c|c|c|c|}
\hline $\begin{array}{l}\text { Food and } \\
\text { particle size }\end{array}$ & $\begin{array}{c}\text { Clearance } \\
\text { rate }\end{array}$ & $\begin{array}{l}95 \% \\
\text { confidence } \\
\text { limits }\end{array}$ & $N$ \\
\hline $\begin{array}{l}\text { Rhizosolenia alata } \\
\text { (living) } \\
1.1 \times 10^{5} \mu \mathrm{m}^{3}\end{array}$ & 601 & 419 to 783 & 8 \\
\hline $\begin{array}{l}\text { R. alata (dead) } \\
1.1 \times 10^{5} \mu \mathrm{m}^{3}\end{array}$ & 378 & 337 to 419 & 8 \\
\hline $\begin{array}{l}\text { Thalassiosira } \\
\text { weissflogii } \\
0.015 \times 10^{5}{\mu \mathrm{m}^{3}}^{3}\end{array}$ & 216 & 174 to 258 & 21 \\
\hline $\begin{array}{l}\text { Fecal pellets of } \\
\text { Paracalanus spp. } \\
0.7 \times 10^{5} \mu \mathrm{m}^{3}\end{array}$ & 226 & 176 to 276 & 13 \\
\hline $\begin{array}{l}\text { Polystyrene spheres } \\
0.042 \times 10^{5} \mu^{3}\end{array}$ & Zero & - & 7 \\
\hline
\end{tabular}

Eucalanus pileatus fed on a wide range of concentrations on living Rhizosolenia alata (Fig. 1) and fecal pellets (Fig. 2). Ingestion rates increased asymptotically and clearance rates decreased significantly ( $p<$ 0.05 ) with increasing particle concentration. When the particle concentration is expressed as nitrogen (Fig. 3), ingestion rates on $R$. alata were significantly higher than on Thalassiosira weissflogii attaining a maximum near $10 \mu \mathrm{gN}^{-1}$. Ingestion rates on pellets, however, continued to increase to $15 \mu \mathrm{gN}$ copepod ${ }^{-1} 24 \mathrm{~h}^{-1}$ at $204 \mathrm{\mu gN}^{-1}$, or about 7 times higher than the ingestion of $R$. alata. Note that at the lower nitrogen concentrations ingestion rates on pellets were between those on $T$. weissflogii and $R$. alata

Eucalanus pileatus $\mathrm{CV}$ were then fed mixtures of 2 types of particles to simulate more natural conditions. 
Fig. 1. Eucalanus pileatus CV Clearance and ingestion rates in relation to average concentration of Rhizosolenia alata. Ingestion rate: $y=$ $610.3\left(1-e^{-1.37 x}\right)$. Clearance rate: $\log y=$ $2.874-0.214 x ; r=-0.770$

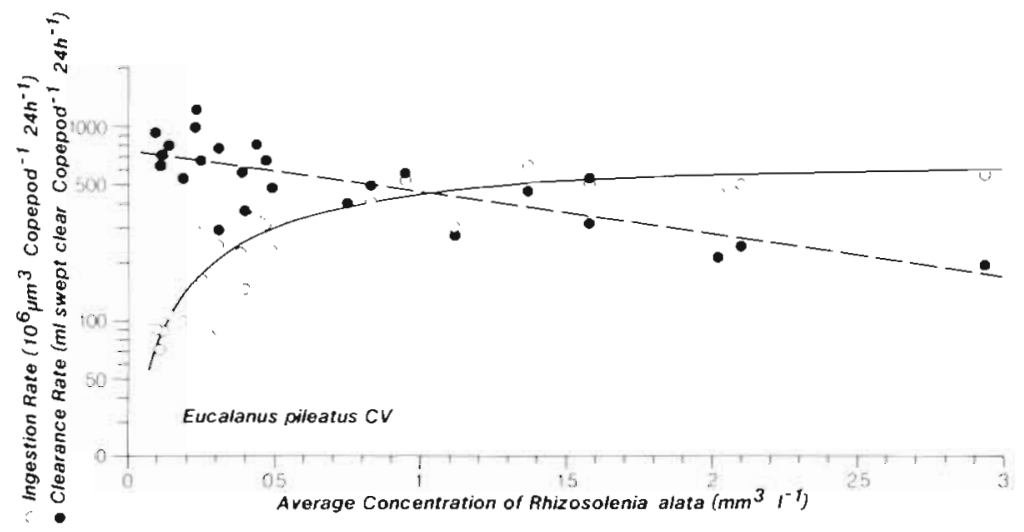

Fig. 2. Eucalanus pileatus $\mathrm{CV}$ Clearance and ingestion rates in relation to average concentration of fecal pellets. Ingestion rate: $y$ $=310.5\left(1-\mathrm{e}^{-0.69 x}\right)$. Clearance rate: $\log y=2.345-0.136 x ; r=$ $-0.668$

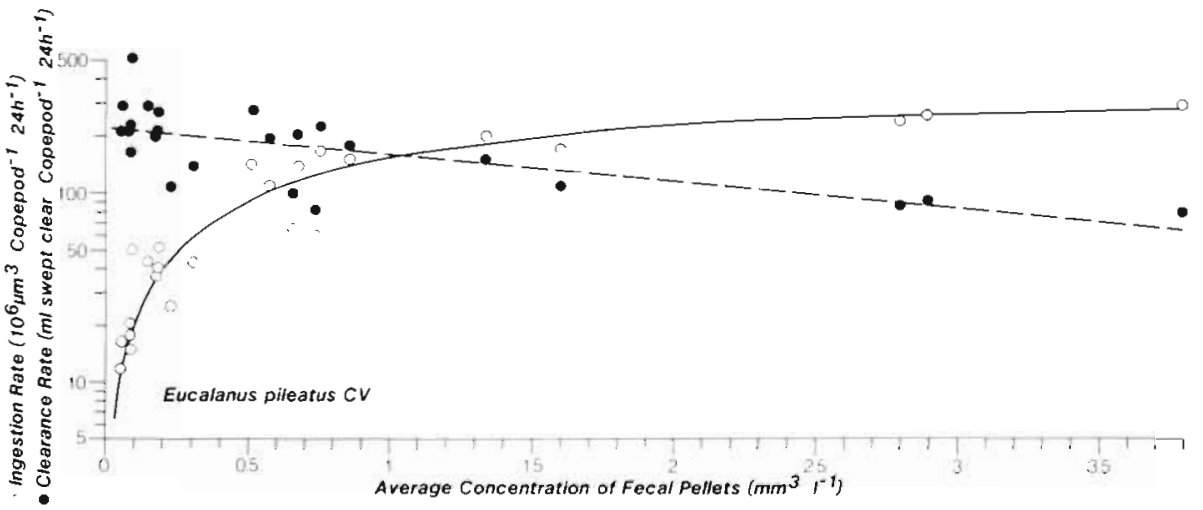

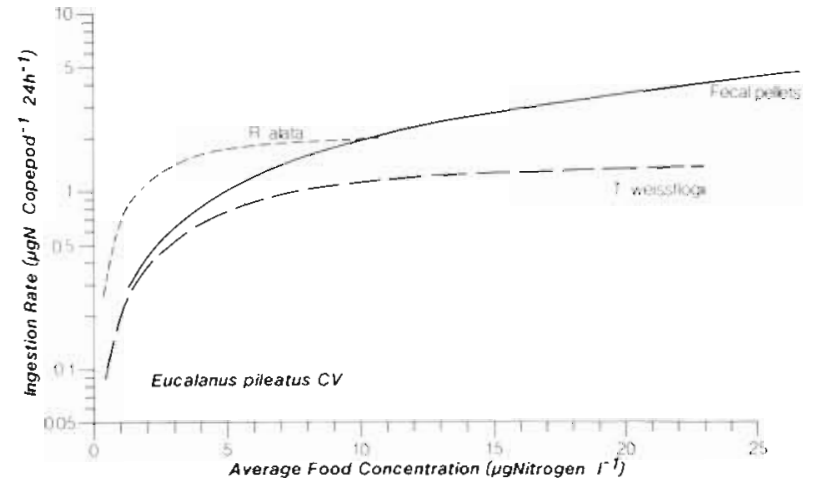

Fig. 3. Eucalanus pileatus CV. Ingestion rates feeding separately on Thalassiosira weissflogii in the presence of $0.3 \mathrm{~mm}^{3}$ $\mathrm{I}^{-1}$ of $20 \mu \mathrm{m}$ diameter beads, on Rhizosolenia alata, and on fecal pellets. For ingestion rate equations see legends of Fig. $1,2 \& 5$

Thalassiosira weissflogii and $20 \mu \mathrm{m}$ beads were offered together, first holding the bead concentration constant and varying the concentration of $T$, weissflogii. We simultaneously ran experiments offering only the diatom, at $0.3 \mathrm{~mm}^{3} \mathrm{l}^{-1}$, to determine whether the presence of beads affected feeding rates on $T$. weissflogii. The clearance rates on $T$. weissflogii and beads both decreased significantly $(p<0.05)$ with increasing concentration of $T$. weissflogii (Fig. 4) with slopes that are not significantly different $(p<0.05)$. Note that the clearance rates of beads when the concentration of $T$. weissflogii was about $0.05 \mathrm{~mm}^{3} \mathrm{l}^{-1}$ are far lower than those when it was near $0.3 \mathrm{~mm}^{3} \mathrm{l}^{-1}$. This result will be discussed later in connection with visual observations. The ingestion of $T$, weissflogii increased asymptotically with increasing diatom concentration attaining its maximum near $1 \mathrm{~mm}^{3} \mathrm{l}^{-1}$ (Fig. 5). Ingestion rates of beads decreased significantly $(p<0.05)$ with increasing diatom concentration. The clearance rates of E. pileatus $C V$ feeding on $T$. weissflogii near $0.3 \mathrm{~mm}^{3} \mathrm{l}^{-1}$ singly and in the mixture did not differ significantly (t-test, $\mathrm{p}<0.05$ in Table 2). Neither did the concentration of cells.

We then offered beads at different concentrations while holding the concentration of Thalassiosira weissflogii constant. Slopes of the clearance rates on both types of particles did not differ significantly from zero (Fig. 6, p > 0.05). Ingestion rates on $T$. weissflogii did not change significantly and on beads increased with increasing bead concentration (Fig. 7). No satiation on beads was evident at the concentrations offered. These results suggest that feeding rates on beads were controlled by the feeding rates on $T$. weissflogii.

We also compared ingestion rates using other similarly sized particles offered singly and in mixture. Living Rhizosolenia alata were ingested at signifi- 

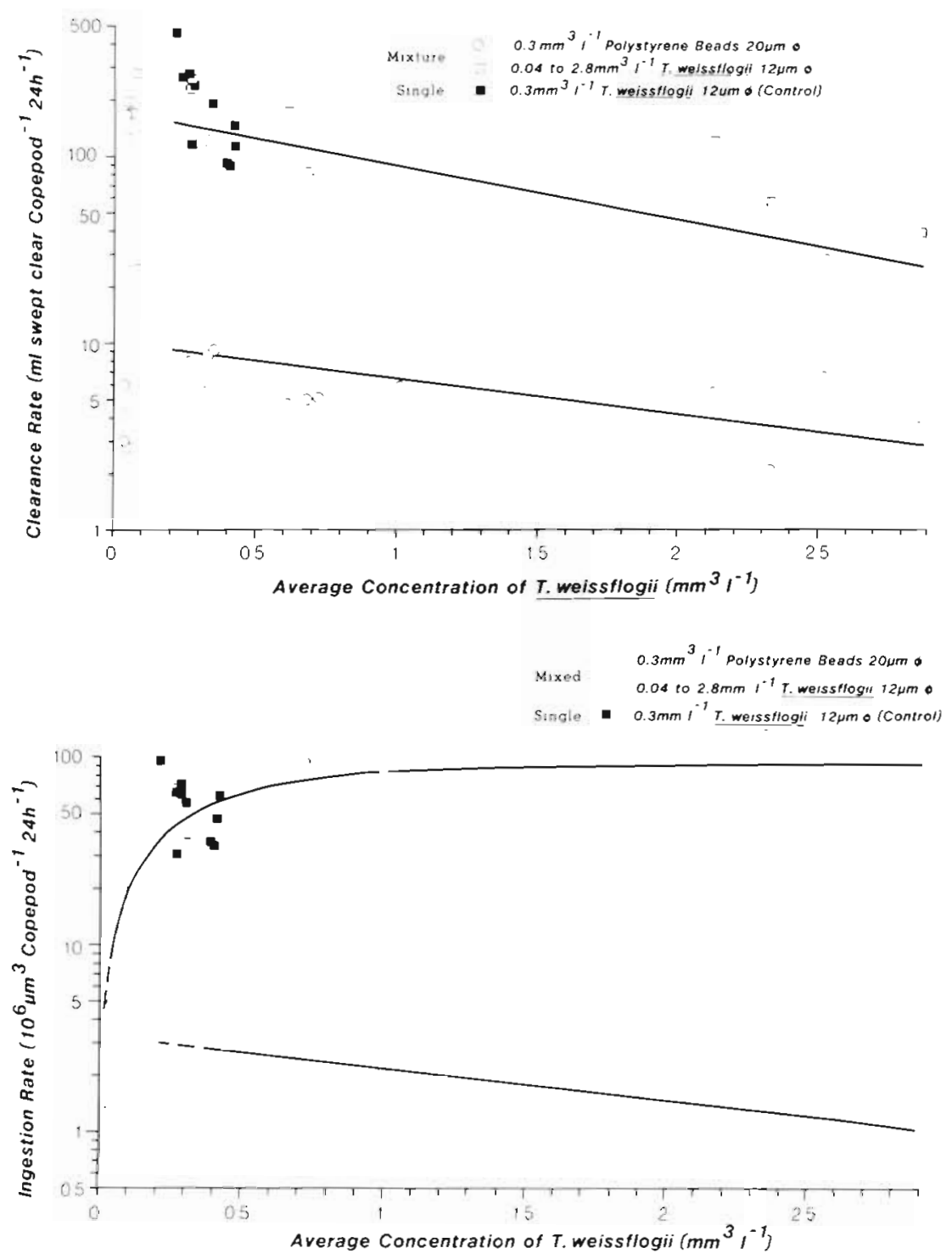

Fig. 4. Eucalanus pileatus CV. Clearance rates feeding simultaneously on beads (non-varying) and Thalassiosira weissflogii (varying), and separately on $T$. weissflogii (control). T. weissflogii: $\log y$ $=2.238-0.282 x_{i} \mathrm{r}=-0.775$. Beads: $\log$ $y=1.001-0.187 x_{i} r=-0.601$
Fig. 5. Same as Fig. 4, except ingestion rates. Thalassiosira weissflogii: $\mathrm{y}=$ 93.55(1- $\left.\mathrm{e}^{-2.37 \mathrm{x}}\right)$. Beads: $\quad \mathrm{y}=$ $0.514-0.169 \mathrm{x}_{i} \mathrm{r}=-0.522$

Table 2. Eucalanus pileatus CV. Clearence rates ( $\mathrm{ml}$ swept clear copepod ${ }^{-1} 24 \mathrm{~h}^{-1}$ ) when offered Thalassiosira weissflogii alone and as a mixture with polystyrene beads, at average concentrations shown $\left(\mathrm{mm}^{3} \mathrm{l}^{-1}\right)$

\begin{tabular}{|c|c|c|c|c|}
\hline Food & Av. food conc. & Clearance rate & $95 \%$ confidence limits & $\mathrm{N}$ \\
\hline T. weissflogii & 0.306 & 198 & 155 to 241 & 15 \\
\hline $\begin{array}{l}T \text { weissflogii } \\
\text { with } 20 \mu \mathrm{m} \text { diameter beads }\end{array}$ & $\begin{array}{l}0.296 \\
0.323\end{array}$ & $\begin{array}{l}182 \\
11.3\end{array}$ & $\begin{array}{l}140 \text { to } 224 \\
8.6 \text { to } 14.0\end{array}$ & $\begin{array}{l}15 \\
15\end{array}$ \\
\hline
\end{tabular}

cantly higher rates than were dead $R$. alata when offered singly and in mixture (Table $3, \mathrm{p}<0.05$, paired t-test). There was no significant difference between food concentrations ( $p<0.05$, paired $t$-test). The rate of ingestion of living $R$. alata was significantly higher than that of pellets singly and in mixture (Table 4 , $\mathrm{p}<0.05$, t-test).

Thalassiosira weissflogii and pellets were also offered singly and in mixture (Table 5). The difference in ingestion rates when these particles were offered singly was not significant, but was significant $(p<$ 0.05 , t-test) when offered together. Food concentrations were not different ( $\mathrm{p}<0.05$, t-test).

We filmed the behavior of Eucalanus pileatus to determine why beads were not ingested when offered alone and were ingested only at lower rates than 

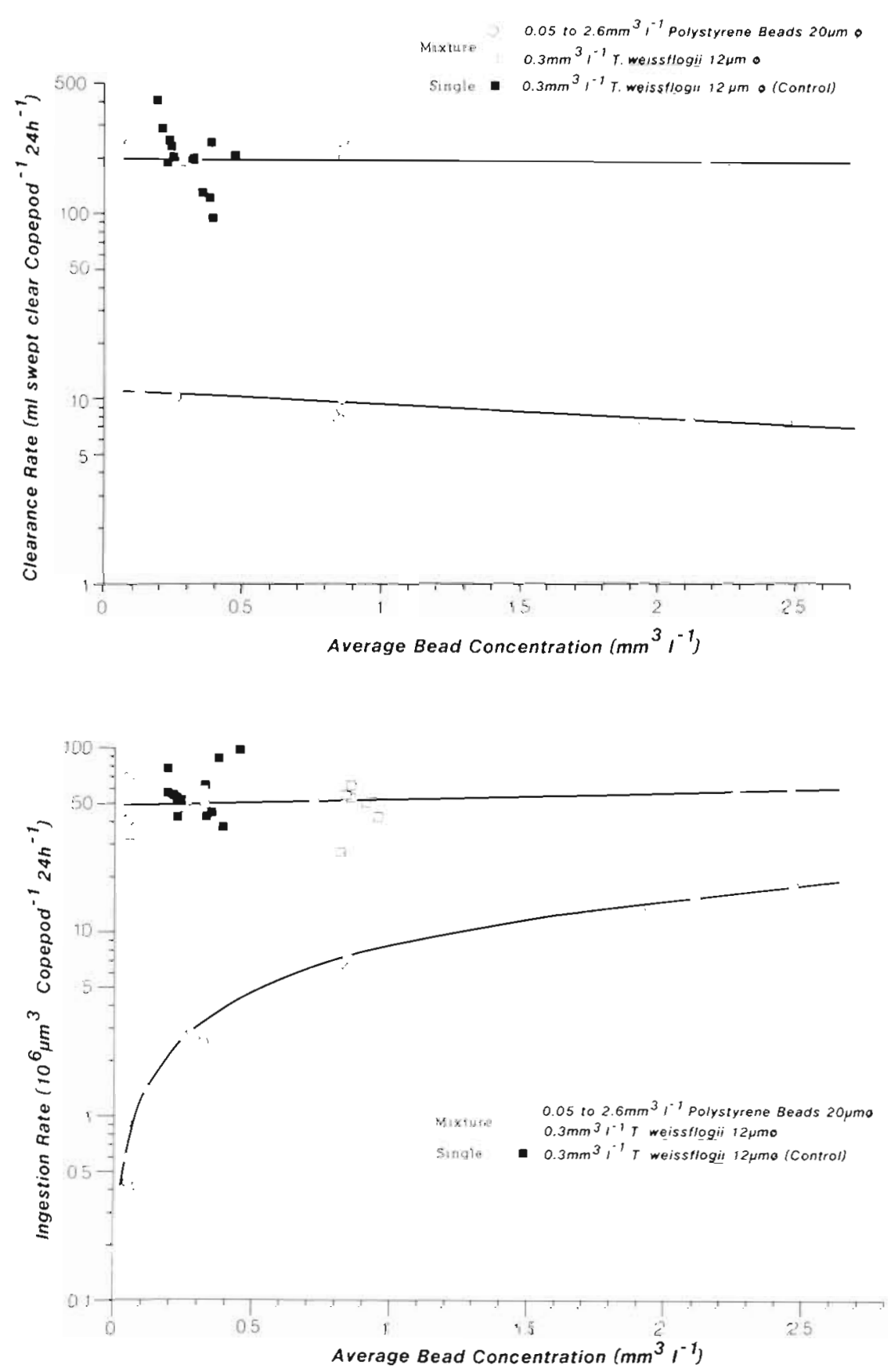

Fig. 6. Same as Fig. 4, except beads (varying) and Thalassiosira weissflogii (nonvarying). $T$. weissflogii: $\log \mathrm{y}=$ $2.299-0.007 x_{i} r=0.058$. Beads: $\log y=$ $1.048-0.071 \mathrm{x} ; \mathrm{r}=0.317$
Fig. 7. Same as Fig. 6, except ingestion rates. Thalassiosira weissflogii: $\log \mathrm{y}=$ $1.682+0.047 ; \mathrm{r}=0.327$. Beads: $\log \mathrm{y}=$ $0.932+0.370 \ln x_{i} r=0.937$

Table 3. Eucalanus pileatus CV. Average ingestion rates $\left(10^{6} \mu \mathrm{m}^{3} \operatorname{copepod}^{-1} 24 \mathrm{~h}^{-1}\right)$ when feeding on Rhizosolenia alata living and dead, alone and in mixtures, at average concentrations shown $\left(\mathrm{mm}^{3} \mathrm{l}^{-1}\right)$

\begin{tabular}{|lccc|}
\hline Food & Av. food conc. & Av. ingestion rate & $95 \%$ confidence limits \\
\hline R. alata living & 0.344 & 182 & 153 to 211 \\
R. alata dead & 0.284 & 107 & 76 to 138 \\
R. alata living (+ dead) & 0.333 & 162 & 128 to 196 \\
R. alata dead (+ living) & 0.262 & 115 & 81 to 149 \\
\hline
\end{tabular}


Table 4. Eucalanus pileatus CV Average ingestion rates $\left(10^{6} \mu \mathrm{m} \operatorname{copepod}^{-1} 24 \mathrm{~h}^{-1}\right)$ when feeding on Rhizosolenia alata and fecal pellets, alone and in mixtures, at average concentrations shown $\left(\mathrm{mm}^{3} \mathrm{l}^{-1}\right)$

\begin{tabular}{lcccc}
\hline Food & Av. food conc. & Av. ingestion rate & $95 \%$ confidence limits & N \\
\hline R. alata (living) & 0.294 & 142 & 97 to 186 \\
Pellets & 0.313 & 66 & 52 to 80 & 9 \\
R. alata (+ pellets) & 0.318 & 140 & 106 to 174 & 8 \\
Pellets (+ R. alata) & 0.274 & 61 & 35 to 87 \\
\hline
\end{tabular}

Table 5. Eucalanus pileatus CV. Average ingestion rates $\left(10^{6} \mu \mathrm{m}^{3}\right.$ copepod $\left.{ }^{-1} 24 \mathrm{~h}^{-1}\right)$ when feeding on Thalassiosira weissflogii and fecal pellets alone and in mixtures, at average concentrations shown $\left(\mathrm{mm}^{3} \mathrm{1}^{-1}\right)$

\begin{tabular}{lccc|}
\hline Food & Av. food conc. & Av. ingestion rate & $95 \%$ confidence limits \\
\hline T. weissflogii & 0.321 & 72 & 53 to 91 \\
Pellets & 0.313 & 66 & 52 to 80 \\
$T$ weissflogii (+ pellets) & 0.318 & 62 & 43 to 81 \\
Pellets + T. weissflogil) & 0.321 & 92 & 73 to 111 \\
\hline
\end{tabular}

Thalassiosira weissflogii in the presence of $T$. weissflogii. Three females were filmed after being offered $1.9 \mathrm{~mm}^{3} \mathrm{l}^{-1}$ of polystyrene beads of $18 \mu \mathrm{m}$ diameter and then repeatedly at $1 \mathrm{~h}$ intervals after adding $T$. weissflogii at $0.4 \mathrm{~mm}^{3} \mathrm{l}^{-1}$. Beads offered alone arrived at the second maxillae without flicks of the other mouthparts and were displaced to the labial palps with or without flings of the second maxillae. Single beads sometimes remained at the labial palps or at the mouth for up to several minutes without being rejected. Rejection processes were started after 3 or more beads accumulated near the mouth. Immediately after $T$. weissflogii was added the copepods began to ingest large quantities of beads. Almost all $T$. weissflogii cells captured were brought to the labial palps and few were rejected. This led us to assume that nearly all were ingested, an assumption which was supported by the frequent appearance of brown material in the copepods' oesophagus. The copepods brought $88 \%$ of the captured beads (beads between the second maxillae) to the mouth and ingested $42 \%$ of them (Table 6). Again, rejection usually occurred after 3 or more beads accumulated at the mouth. Even then some of the beads were repeatedly returned to the labial palps.

The ratio of the number of Thalassiosira weissflogii cells $\left(0.4 \mathrm{~mm}^{3} \mathrm{l}^{-1}\right)$ to the number of beads $\left(1.9 \mathrm{~mm}^{3} \mathrm{l}^{-1}\right)$ ingested averaged 11.5 in feeding experiments and 5.8 at the same concentrations in film observations. In feeding experiments and film observations we used $20 \mu \mathrm{m}$ beads and $\mathrm{CV}$, and $18 \mu \mathrm{m}$ beads and adult females, respectively. Therefore, to compare the ratios noted above we substituted equivalent volumes of 18
Table 6. Eucalanus pileatus females. Average numbers of captures and ingestions of beads and Thalassiosira weissflogii during $16 \mathrm{~s}$ (from films)

\begin{tabular}{|lcc|}
\hline & Beads alone & $\begin{array}{c}\text { Beads with } \\
T \text {. weissflogii }\end{array}$ \\
\hline No. of beads captured & 6.3 & 9.0 \\
$\begin{array}{l}\text { No. of beads arriving } \\
\text { at labial palps }\end{array}$ & 4.7 & 7.9 \\
(\% of captured) & $(75)$ & $(88)$ \\
$\begin{array}{l}\text { No. of beads ingested } \\
\text { \% of captured) }\end{array}$ & None & 3.8 \\
$\begin{array}{l}\text { No. of } T \text {. weissflogii } \\
\text { cells captured }\end{array}$ & & $(42)$ \\
$\begin{array}{l}\text { No. of } T \text { weissflogii } \\
\text { cells arriving } \\
\text { at labial palps }\end{array}$ & & 21.0 \\
\hline
\end{tabular}

$\mu \mathrm{m}$ beads $\left(623000\right.$ beads $\left.=1.9 \mathrm{~mm}^{3}\right)$ for those of $20 \mu \mathrm{m}$ (454 000 beads $=1.9 \mathrm{~mm}^{3}$ ). This resulted in a ratio of 8.3 for our experiments which is still $43 \%$ higher than that of 5.8 found in film observations.

Observations on the capture of fecal pellets ( 5 films) revealed that on average $66 \%$ of the captured pellets were brought to the second maxillae by flicks of the other mouthparts, usually by the second antennae (A2) and maxillipeds (MxP). Sixty-three \% of the captured Thalassiosira weissflogii cells were directed to the second maxillae by flicks of mouthparts other than second maxillae (M2). Only 1 of 15 beads captured by the M2 was directed to the M2 by a flick. Pellets were sensed by the mouthparts (e.g. A2, MxP) only when 
almost touching them and then were directed towards the M2 by a flick.

\section{DISCUSSION}

Our results show that Eucalanus pileatus ingests beads, living, and dead organic particles at different rates. At equal volumetric concentrations about 3 times more phytoplankton cells are eaten than similarly sized fecal pellets. Beads, which have no nutritional value, are eaten at only one-twentieth the rate of phytoplankton of similar volume when both are available.

What causes such differences? Clearance and ingestion rates are a function of the long-range (olfactory) and short-range chemoreception of Eucalanus pileatus. Long-range chemoreception governs particle capture and short-range chemoreception at the mouth governs particle ingestion. Beads brought into the copepod's feeding current are not perceived individually by any of the mouth-parts unless they touch, and then practically only by the M2. Thus, only beads in a small cross-section of the feeding current, which includes the M2, could be perceived. However, $63 \%$ of the Thalassiosira weissflogii cells which arrive at the M2 are brought there by flicks of other mouthparts. These mouthparts can perceive the approaching alga and direct it towards the M2 (Strickler 1982). This means that $T$. weissflogii is perceived over a larger part of the cross-section of the feeding current than are beads. As the percentage of diatom cells perceived and directed by individual mouthpart flicks increases with the diatom's volume (Price \& Paffenhofer in press), a larger percentage of captured Rhizosolenia alata than $T$. weissflogii were brought to the M2 by flicks. The percent perception and capture of individual particles is related to the copepod's feeding rate, as shown for pellets and $T$. weissflogii cells which are eaten at similar rates (Table 1). Similar behavior has been described for Eucalanus elongatus (Price \& Paffenhöfer in press). These observations lead us to conclude that the percentage of pellets perceived individually is much lower than that of the similarly sized $R$, alata.

The reasons for this lower perception percentage can only be guessed. Three possibilities are: (1) chemical compounds responsible for the perception may have been modified due to digestion processes; (2) the chemicals cannot be released as readily from the pellet as from the cell due to dense packaging of particulate matter in the pellet; $(3)$ the pellet membrane's permeability for the respective chemicals is probably different from that of the cell's. Mechanoreception cannot be excluded (Strickler 1984) but seems unlikely as copepod fecal pellets of a volume similar to that of the $20 \mu \mathrm{m}$ diameter beads, which were not individually perceived, were eaten at an average clearance rate of
$101 \mathrm{ml}$ swept clear $\mathrm{CV}^{-1} 24 \mathrm{~h}^{-1}$. Mechanoreception could trigger the capture of moving food particles in the $20 \mu \mathrm{m}$ range such as ciliates and nauplii.

Olfactory responses as described above occur irrespective of copepods being preconditioned to a certain type of food particle. However, detection of cells by olfaction does not need to imply ingestion. Fecal pellets, gathered by non-preconditioned Eucalanus pileatus females were usually tasted and then rejected. Females of Paracalanus sp. did gather but not ingest Thalassiosira weissflogii when they were not preconditioned to that food species. It appears that, following detection by olfaction, short-range chemoreception accurs at or near the mouth, where the decision for or against ingestion is made (Paffenhöfer et al. 1982). Usually a single bead elicits no decision; the signals received are sub-threshold. However, algae and pellets provide enough signals. Rhizosolenia alata was usually eaten immediately upon arrival at the mouth. Beads were ingested with the algal cells. As beads were not individually perceived, they constituted only about $5 \%$ of the total ingested volume when there were equal concentrations of $T$. weissflogii and beads. Beads were rejected when 3 or more had been accumulated and none or an insufficient number of $T$. weissflogii cells had arrived at the mouth. This explains the low clearance and ingestion rates of beads at $0.05 \mathrm{~mm}^{3}$ $1^{-1}$ of $T$. weissflogii (Fig. 4 \& 5). Fecal pellets which arrive at the mouth are opened or slightly macerated before ingestion or rejection occurs. This is not regularly seen with $T$. weissflogii cells.

As beads are not ingested when offered alone, as the clearance rate on Thalassiosira weissflogii at $0.3 \mathrm{~mm}^{3}$ $1^{-1}$ is the same in the absence and presence of beads (Table 2, Fig. 6), and as the clearance rate on beads decreases at a rate similar to that on $T$. weissflogii (Fig. 4), we conclude that the feeding rate on non-food particles, like polystyrene beads, is a function of the feeding rate on food particles. Eucalanus pileatus, and probably many other calanoid species, possess a behavior that prevents or reduces the intake of particles of little or no food value. The long- and shortrange chemoreception of $E$. pileatus assure that particles of high food quality and quantity are preferentially captured and eaten. This implies that E. pileatus and other species have developed behaviors that assure that a high percentage of the ingested particles are of high quality even when particles of low value are more abundant.

The question arises as to how data on tethered copepods compare with those on free-swimming ones. Our results showed that free-swimming copepods ingested 8.3 Thalassiosira weissflogii cells while ingesting 1 bead as compared to tethered copepods with a ratio of 5.8 to 1 at concentrations of $1.99 \mathrm{~mm}^{3} \mathrm{l}^{-1}$ 
of beads and $0.4 \mathrm{~mm}^{3} \mathrm{l}^{-1}$ of $T$. weissflogii. One explanation for the higher percentage of bead ingestions by tethered animals could be that a female may reject beads at a lower rate than a $\mathrm{CV}_{\text {; }}$ as the latter being smaller has less space between the labial palps than a female and thus cannot keep more than 1 bead at a time. Free-swimming copepods were $C V$, while the tethered ones were fertilized females. These females ingested $T$. weissflogii at an average of $386 \mathrm{ml}$ swept clear copepod ${ }^{-1} 24 \mathrm{~h}^{-1}$. In previous experiments with free-swimming animals, $290 \mathrm{ml}$ were swept clear (Eucalanus female) $)^{-1} 24 \mathrm{~h}^{-1}$ of $T$. weissflogii when it and Prorocentrum micans each were offered at an average of $0.4 \mathrm{~mm}^{3} \mathrm{l}^{-1}$ (Paffenhöfer 1984). A fastened calanoid, at non-satiating food concentrations, will obtain more food, as it can create a stronger/faster feeding current, thus displacing more algae towards itself as compared to a free-swimming one (see Strickler 1982).

Numerous studies have been conducted on the feeding of calanoid copepods on living and dead algae, fecal pellets and non-food particles. We discuss the results and conclusions from some of these studies and attempt to arrive at some general conclusions.
Living food particles. The feeding response of Eucalanus pileatus $\mathrm{CV}$ to increasing concentrations of 2 diatoms, Thalassiosira weissflogii and Rhizosolenia alata, was similar to that observed for other species of copepods (e.g. Frost 1972, Checkley 1980) in that satiation was observed at relatively low volumetric and nitrogen concentrations. While the ingestion rates of different diatoms by Calanus pacificus females were identical at and beyond critical concentrations (Frost 1972), those of $E$. pileatus were near 2.0 for $R$. alata and $1.4 \mu \mathrm{gN} \mathrm{CV}^{-1} \mathrm{~d}^{-1}$ for $T$. weissflogii.

Non-living food particles. Dead organic particles are ingested at rates lower than living particles (Table 7). These particles could be dead cells, whole or fractionated fecal pellets, dead macrophyte particles, dead animals or aggregations of a variety of living and dead particles. Previous studies (Table 7) covered clearance rates when calanoid copepods were offered dead and living particles separately and together. The copepod rates of clearance on non-living algae were between 52 and $90 \%$ of the rates on living algae with an average of $63 \%$. The reduced rates of clearance on dead cells could be partly attributed to a reduced nitrogen content (Cowles et al. pers. comm.). The nitro-

Table 7. Clearance rates of calanoid copepods (ml swept clear copepod ${ }^{-1} 24 \mathrm{~h}^{-1}$ ) on non-living particles as compared with those on living

\begin{tabular}{|c|c|c|c|c|c|c|}
\hline Copepod species & $\begin{array}{l}\text { Non-living } \\
\text { particle }\end{array}$ & $\begin{array}{l}\text { Clearance } \\
\text { rate }\end{array}$ & $\begin{array}{l}\text { Living } \\
\text { particle }\end{array}$ & $\begin{array}{l}\text { Clearance } \\
\text { rate }\end{array}$ & $\begin{array}{l}\text { Clearance on } \\
\text { non-living } \\
\text { as } \% \text { of living }\end{array}$ & Source \\
\hline \multirow[t]{3}{*}{$\begin{array}{l}\text { Calanus } \\
\text { helgolandicus } \\
\text { females }\end{array}$} & $\begin{array}{l}\text { Skeletonema } \\
\text { costatum }\end{array}$ & 54 & $\begin{array}{l}\text { Chaetoceros } \\
\text { curvisetus }\end{array}$ & 60 & 90 & $\begin{array}{l}\text { Paffenhöfer } \\
\& \text { Strickland } \\
1970\end{array}$ \\
\hline & $\begin{array}{l}\text { Ditylum } \\
\text { brightwellii }\end{array}$ & 31 & & & 52 & \\
\hline & Fecal material & 10 & & & 17 & \\
\hline $\begin{array}{l}\text { Eucalanus } \\
\text { pileatus } \\
\text { females }\end{array}$ & $\begin{array}{l}\text { Naupliar } \\
\text { fecal pellets }\end{array}$ & 275 & $\begin{array}{l}\text { Rhizosolenia } \\
\text { alata }\end{array}$ & 301 & 92 & $\begin{array}{l}\text { Paffenhöfer } \\
\& \text { Knowles } \\
1979\end{array}$ \\
\hline $\begin{array}{l}\text { Diaptomus } \\
\text { spatulocrematus }\end{array}$ & $\begin{array}{l}\text { Chlamydomonas } \\
\text { renhardti }\end{array}$ & 20.2 & $\begin{array}{l}\text { Same species } \\
\text { as non-living }\end{array}$ & 36.6 & 55 & $\begin{array}{l}\text { Starkweather } \\
\& \text { Bogdan } 1980\end{array}$ \\
\hline $\begin{array}{l}\text { Paracalanus } \\
\text { parvus }\end{array}$ & $\begin{array}{l}\text { Thalassiosira sp. } \\
\text { D. brightwelli }\end{array}$ & 91 & $\begin{array}{l}\text { Same species } \\
\text { as non-living }\end{array}$ & 144 & 63 & Bartram 1981 \\
\hline $\begin{array}{l}\text { Acartia tonsa } \\
\text { females }\end{array}$ & $\begin{array}{l}\text { Same as for } \\
P . \text { parvus }\end{array}$ & 78 & $\begin{array}{l}\text { Same species } \\
\text { as non-living }\end{array}$ & 112 & 69 & \\
\hline \multirow[t]{2}{*}{$\begin{array}{l}\text { Eucalanus } \\
\text { pileatus } \mathrm{CV}\end{array}$} & $\begin{array}{l}\text { Rhizosolenia alatal } \\
\text { R. alata }\end{array}$ & $\begin{array}{l}378 \\
460\end{array}$ & $\begin{array}{l}\text { Same species } \\
\text { as non-living }\end{array}$ & $\begin{array}{l}601 \\
553\end{array}$ & $\begin{array}{l}63 \\
83\end{array}$ & This study \\
\hline & $\begin{array}{l}\text { Fecal pellets } \\
\text { Fecal pellets }\end{array}$ & $\begin{array}{l}226 \\
213\end{array}$ & $\begin{array}{l}\text { R. alata } \\
\text { R. alata }\end{array}$ & $\begin{array}{l}524 \\
483\end{array}$ & $\begin{array}{l}43 \\
44\end{array}$ & \\
\hline $\begin{array}{l}1 \text { Non-living and } \\
2 \text { Same as above } b\end{array}$ & $\begin{array}{l}\text { iving particles offered } \\
\text { ut offered in a mixtur }\end{array}$ & separately & & & & \\
\hline
\end{tabular}


gen content of dead Rhizosolenia alata cells offered in our experiments ranged from 50 to $70 \%$ of that of living cells. Similarly-sized fecal pellets were removed at rates between 43 and $92 \%$ of living phytoplankton cells (Table 7). The increased ingestion of pellets in the presence of Thalassiosira weissflogii (Table 5) is attributed to an increased capture rate as observed for beads in the presence of $T$. weissflogii (Table 6). Detrital particles (the macrophyte Thalassia testudinum) were eaten at similar rates with or without diatoms by Copepodid Stage $\mathrm{V}$ and adult Acartia tonsa (Roman 1984). This similarity of rates is attributed to the size of most of the detritus particles being in the range from 8 to $12 \mu \mathrm{m}$ Equivalent Spherical Diameter (Roman 1984).

Non-food particles. Several studies with 3 copepod species offered plastic spheres yielded differing results. Different stages of Acartia tonsa ingested different sizes of plastic (inert) spheres in the absence of food in experiments run for about $15 \mathrm{~min}$ (Wilson 1973). Acartia clausii avoided eating inert spheres after the first few minutes of being exposed to them even when phytoplankton cells were present (Donaghay \& Small 1979). Later, when spheres and beads were offered at equal concentrations, spheres were ingested at very low rates (Donaghay 1980). The ratio of ingested cells to ingested beads was 198:1 which is much higher than the 8.3:1 which we found for Eucalanus pileatus at $1.99 \mathrm{~mm}^{3} \mathrm{l}^{-1}$ of beads and $0.39 \mathrm{~mm}^{3} \mathrm{l}^{-1}$ of Thalassiosira weissflogii. A. clausii thus appears to optimize algal intake even more than $E$. pileatus. This is an important factor in estuarine environments where non-living particles of low food value usually dominate the particulate matter available to copepods. Wilson's (1973) observations should be interpreted with caution as extended ingestion of inert spheres by Acartia spp. is questionable.

Late copepodid stages and adult females of Calanus pacificus ingest large amounts of spheres in the presence of phytoplankton (Frost 1977, Huntley et al. 1983). Frost (1977) found that the size frequency distribution of the ingested spheres was not skewed toward larger sizes as was the case for phytoplankton cells; the frequency distribution of ingested beads was similar during all treatments. We believe this non-skewed frequency distribution resulted from a random capture of all bead sizes offered, excluding the $6.4 \mu \mathrm{m}$ beads. While $C$. pacificus 'was reluctant to ingest plastic spheres unless nutritional particles were present' (Frost 1977), the same species ingested spheres at similar rates in the presence and absence of phytoplankton (Huntley et al. 1983). Both C. pacificus and $E$. pileatus ingested algal cells at higher rates than similarly-sized spheres, the ratios being about 20:1 for both species when Thalassiosira weissflogii and spheres of 16.5 to $20 \mu \mathrm{m}$ diameter were offered at similar concentrations. As the percentage of spheres in a mixture of spheres and diatoms increased, the clearance rate on diatoms decreased and that on spheres remained constant (Huntley et al. 1983). In our studies with $E$. pileatus a 10 -fold increase in sphere concentration from 0.25 to $2.5 \mathrm{~mm}^{3} \mathrm{l}^{-1}$ did not change clearance rates either on $T$. weissflogii or on spheres (Fig. 6).

When we compare the feeding responses of Eucalanus pileatus to increasing concentrations of diatoms, fecal pellets, and polystyrene beads, we observed satiation at $\mathrm{ca} 10$ to $20 \mu \mathrm{gN}^{-1}$ for the diatoms (Fig. 8), none for the fecal pellets at this range

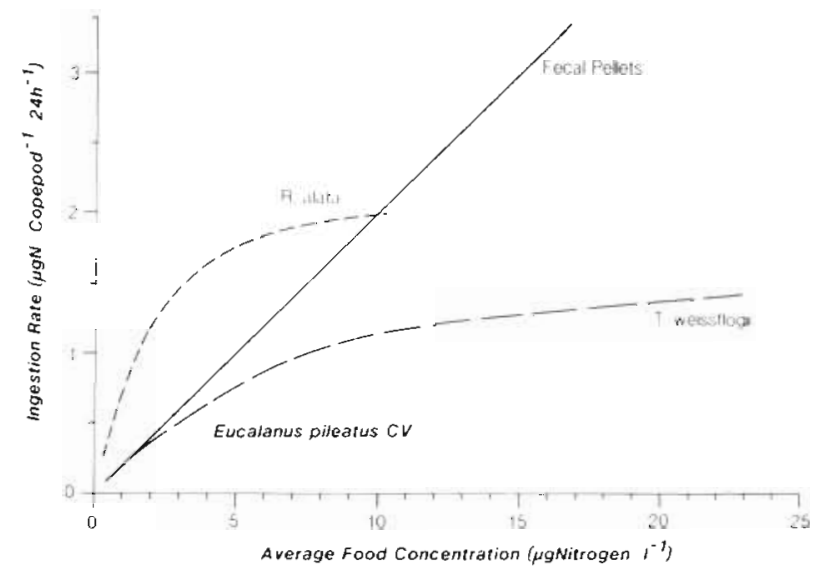

Fig. 8. Eucalanus pileatus. Fig. 3 is presented linearly for comparison with Mayzaud \& Poulet (1978) and Roman (1984).

For ingestion rate equations see legends of Fig. 1, 2 \& 5

of environmental particulate matter (Fig. 8) and none for spheres (Fig. 7). There is no solid evidence to explain why $E$. pileatus became satiated with living algae but did not at similar nitrogen concentrations with fecal material. Phytoplankton nitrogen, not carbon, was the variable determining satiation in Paracalanus parvas (Checkley 1980). The actual amount of nitrogen assimilated by copepods and not the particle or food concentration should govern satiation. The amount assimilated is a function of ingestion rate, nitrogen content of particles, gut fullness, digestibility/ availability of food compounds, digestive enzyme activity and assimilative capability of the copepod. Several of these variables probably depend on preconditioning to food type and concentration (Mayzaud \& Poulet 1978, Donaghay \& Small 1979, Price \& Paffenhöfer 1984). The difference in the copepod's response to diatoms and non-living particles may lie in the amount of nitrogen or energy which it can extract from the respective food sources. If it cannot obtain or extract much from ingested matter, then the residence time of that matter in the gut should be short (e.g. fecal pellets: no satiation, Fig. 8); if the copepod obtains 
much energy/nitrogen from the ingested material, then the food's residence time in the gut should be long (e.g. larger algae like Rhizosolenia alata: satiation, Fig. 8). We observed continuous ingestion of diatoms by $E$. pileatus at lower food concentrations $\left(0.3 \mathrm{~mm}^{3} \mathrm{l}^{-1}\right)$; at concentrations above $1 \mathrm{~mm}^{3} \mathrm{l}^{-1}$ this copepod species did not ingest diatoms during regularly occurring periods (minutes), i.e. ingestion was not continuous.

Our observations and those of Roman (1984) suggest the hypothesis that satiation of a copepod is a function of the amount of utilizable nitrogen or energy in its food. Acartia tonsa, feeding on Thalassiosira weissflogii at concentrations from about 150 to $900 \mathrm{kgC} \mathrm{^{-1 }}$, became satiated near $300 \mu \mathrm{gC} \mathrm{l}^{-1}$ (Roman 1984, his Fig. 2). However, when $A$. tonsa was offered macrophyte detritus alone, and then with $T$. weissflogii at $360 \mu \mathrm{gC}^{-1}$, no satiation was observed (Roman 1984, his Fig. 1). The same response of non-satiation was found when $T$. weissflogii was offered with large amounts of detritus $\left(1173 \mu \mathrm{gC}^{-1}\right.$, his Fig. 2). In essence, satiation of $A$. tonsa occurred when $T$. weissflogii was offered alone, as observed for $E$. pileatus, or with small amounts of detritus. This detritus had little if any food value as shown by high mortality rates of young copepods (his Fig. 3). These results indicate that the presence of large amounts of particles which have a low nitrogen content or whose nitrogen is not utilized by the copepod prevents satiation of $A$. tonsa.

The linear increase in ingestion rate by Eucalanus pileatus offered beads in the presence of low concentrations of Thalassiosira weissflogii is similar to results with Acartia tonsa feeding on detritus (Roman 1984, his Fig. 1), and to those with E. pileatus feeding on fecal pellets over the environmental range of nitrogen concentration on the southeastern continental shelf of the USA (Fig. 8).

How do these observations compare to those of Mayzaud \& Poulet (1978) and Conover (1978) who did not find satiation responses for 6 copepod species? In Bedford Basin an average of $21 \%$ of the total particulate organic carbon is living (Poulet 1976), implying that non-living organic particles predominate. This ratio is similar to those in some experiments by Roman's (1984) who offered relatively low amounts of Thalassiosira weissflogii with detritus. Ingestion rates in both cases (Mayzaud \& Poulet 1978, Roman 1984) increased evenly with increasing particle concentration, similar to our findings for Eucalanus pileatus feeding on beads in the presence of low concentrations of $T$. weissflogii, and on fecal pellets.

What causes linear increase in uptake or what prevents satiation? First, small phytoplankton cells, detritus and non-food particles are poorly perceived individually, resulting in low ingestion rates. Second, detritus particles (dead cells) are low in nitrogen and the copepods do not have the enzymes to utilize some (e.g. the macrophyte Thalassia testudinum). Third, utilization or assimilability of nitrogen from detritus particles with high nitrogen content, like pellets, could be much lower than for phytoplankton. Pellets are densely packed with material which may not allow enzymes to reach all of the material. Fourth, the abundance of individually well-perceived cells could have been low, resulting in overall low ingestion rates. Fifth, the relatively large amount of detritus or nonfood particles ingested with the larger cells could result in reduced digestion or assimilation of cell nitrogen.

The variables that influence clearance rates at nonsatiating particle concentrations are poorly understood, although indirect evidence suggests that chemical signals are largely responsible (Poulet \& Marsot 1978). Our data suggests that chemical perception of potential food particles is responsible for their capture. Signal strength, and therefore rates of capture and feeding, could be a function of cell size (Price \& Paffenhöfer in press) or nutritional content and should prevent indulgence by a copepod with particles of little or no food value. One of our next steps should be to determine the chemical compounds which trigger (1) particle capture and (2) their ingestion.

Acknowledgements. This research was supported by NSFGrant OCE81-17761 and DOE Contract DE-AS09-76EV00936. Mr. Brian Spaulding performed some of the experiments. Dr. Eileen E. Hofmann calculated the curvilinear equations. Drs. D. W. Menzel, H. J. Price and D. E. Steams critically reviewed an earlier version of this manuscript. Ms. Dannah McCauley typed the manuscript. Ms. Suzanne McIntosh and Ms. Anna Boyette prepared the figures. The authors acknowledge their advice and support.

\section{LITERATURE CITED}

Alldredge, A. L. (1981). The impact of appendicularian grazing on natural food concentrations in situ. Limnol. Oceanogr. 26: 247-257

Bartram, W C. (1981). Experimental development of a model for the feeding of neritic copepods on phytoplankton. J. Plankton Res. 3: 25-51

Checkley, D. M. (1980). The egg production of a marine planktonic copepod in relation to its food supply: Laboratory studies. Limnol. Oceanogr. 25: 430-446

Conover, R. J. (1978). Feeding interactions in the pelagic zone. Rapp. P.-v. Réun. Cons. int. Explor. Mer 173: 66-76

Conover, R. J., Huntley, M. E. (1980). General rules of grazing in the pelagic ecosystem. In: Brookhaven Symposium in Biology 31. Brookhaven National Laboratory, Upton, New York, p. 461-485

Donaghay, P. L. (1980). Ciazing interactions in the marine environment. In: Kerfoot, W. C. (ed.) The evolution and ecology of zooplankton communities. Univ. Press of New England, Hanover, New Hampshire, p. 234-240

Donaghay, P. L., Small, L. T (1979). Food selection capabilities of the estuarine copepod Acartia clausii. Mar. Biol. 52: 137-146 
Fernandez, F. (1979). Particle selection in the nauplius of Calanus pacificus. J. Plankton Res. 1: 313-328

Frost, B. W. (1972). Effects of size and concentration of food particles on the feeding behavior of the marine planktonic copepod Calanus pacificus. Limnol. Oceanogr. 17: 805-815

Frost, B. W. (1977). Feeding behavior of Calanus pacificus in mixtures of food particles. Limnol. Oceanogr. 22: 472-491

Gerber, R. P., Marshall, N. (1974). Ingestion of detritus by the lagoon pelagic community at Eniwetok Atoll. Limnol. Oceanogr. 19: 815-824

Guillard, R. R., Ryther, J. H. (1962). Studies of marine planktonic diatoms. I. Cyclotella nana Hustedt, and Detonula confervacea (Cleve) Gran. Can. J. Microbiol. 8: 229-239

Harbison, G. R., McAlister, V. L. (1979). The filter-feeding rates and particle retention efficiencies of three species of Cyclosalpa (Tunicata, Thaliacea). Limnol. Oceanogr. 24: 875-892

Huntley, M. E., Barthel, K.-G., Star, J. L. (1983). Particle rejection by Calanus pacificus: Discrimination between similarly sized particles. Mar. Biol. 74: 151-160

Lohmann, H. (1909). Die Gehäuse und Gallertblasen der Appendicularien und ihre Bedeutung für die Erforschung des Lebens im Meer. Verh. dt. zool. Ges. 19: 200-239

Mayzaud, P., Poulet, S. A. (1978). The importance of the time factor in the response of zooplankton to varying concentrations of naturally occurring particulate matter. Limnol. Oceanogr. 23: 1144-1154

Paffenhöfer, G.-A. (1972). The effects of suspended 'Red Mud' on mortality, body weight, and growth of the marine planktonic copepod, Calanus helgolandicus. Wat., Air Soil Pollut. 1: $314-321$

Paffenhöfer, G.-A. (1984). Calanoid copepod feeding: Grazing on small and large particles, In: Meyers, D. G., Strickler, J. R. (ed.) Trophic interactions within aquatic ecosystems. AAAS Selected Symposium 85, Westview Press, Boulder, Colorado, p. 75-95

Paffenhöfer, G.-A., Strickler, J. R., Alcaraz, M. (1982). Suspension-feeding by herbivorous calanoid copepods: A cinematographic study. Mar. Biol. 67: 193-199
Paffenhöfer, G.-A., Knowles, S. C. (1979). Ecological implications of fecal pellet size, production and consumption by copepods. J. mar. Res. 37: 35-49

Paffenhöfer, G.-A., Strickland, J. D. H. (1970). A note on the feeding of Calanus helgolandicus on detritus. Mar. Biol. 5: 97-99

Poulet, S. A. (1976). Feeding of Pseudocalanus minutus on living and non-living particles. Mar. Biol. 34: 117-125

Poulet, S. A. (1983). Factors controlling utilization of nonalgal diets by pelagic grazing copepods: A review. Oceanologica Acta 6: 221-234

Poulet, S. A., Marsot, P. (1978). Chemosensory grazing by marine calanoid copepods (Arthropoda: Crustacea). Science N. Y., 200: 1403-1405

Price, H. J., Paffenhöfer, G.-A., Strickler, J. R. (1983). Modes of cell capture in calanoid copepods. Limnol. Oceanogr. 28: 116-123

Price, H. J., Paffenhöfer, G.-A. (1984). Effects of feeding experience in the copepod Eucalanus pileatus: A cinematographic study. Mar. Biol. 84: 35-40

Price, H. J., Paffenhöfer, G.-A. (1985). Perception of food availability by calanoid copepods. In: Lampert, W. (ed.) Food limitation and the structure of zooplankton communities. Arch. Hydrobiol. (Beih.) Ergeb. Limnol. (in press)

Roman, M. R. (1984). Utilization of detritus by the copepod, Acartia tonsa. Limnol. Oceanogr. 29: 949-959

Starkweather, P. L., Bogdan, K. G. (1980). Detrital feeding in natural zooplankton communities: Discrimination between live and dead algal food. Hydrobiologia 73: 83-85

Strickler, J. R. (1982). Calanoid copepods, feeding currents, and the role of gravity. Science 218: $158-160$

Strickler, J. R. (1984). Sticky water: A selective force in copepod evolution. In: Meyer, D. G., Strickler, J. R. (ed.) Trophic interactions within aquatic ecosystems. AAAS Symposium 85, Westview Press, Boulder, Colorado, p. $187-239$

Wilson, D. S. (1973). Food size selection among copepods. Ecology 54: 909-914 